\title{
Análise do comportamento mecânico de vigas de madeira maciça com sistema de protensão por cabos de aço
}

\section{Introdução}

Em meio a tantos materiais de construção, a madeira possui diversas propriedades de interesse técnico e econômico para a construção civil. O baixo consumo de energia para seu processamento e a característica sustentável intrínseca à sua obtenção, além de ser de fácil manuseio no canteiro de obras, fornecem aspectos vantajosos à economia. Por fim, a elevada resistência mecânica à tração e à compressão a torna capaz de ser empregada como material estrutural (TAZARV; CARNAHAN; WEHBE, 2019). A madeira, quando empregada de forma estrutural, apresenta grandes deformações até sua ruptura, sendo considerada um material dúctil. Tal comportamento é satisfatório para a segurança estrutural, porém é possível afirmar que sua rigidez física é intermediária ou baixa, acarretando deslocamentos excessivos antes de se atingir sua capacidade de carga resistente máxima. Para aumentar a eficiência de sua resistência, é necessário atenuar o seu deslocamento vertical quando aplicada como um elemento de viga sob flexão. Novas alternativas têm sido estudadas, dentre elas o uso de materiais de reforço com maior rigidez física e a protensão de elementos elásticos (D’AVENI; D'AGATA, 2017). Neste trabalho, foi desenvolvido um sistema de protensão em vigas de madeira maciça da espécie Eucalyptus Saligna.

\section{Metodologia}

Foi realizado um comparativo de comportamento em relação à capacidade de carga, à rigidez da viga e à flecha máxima. Para aferir esses resultados, foram realizados oito en-

\footnotetext{
${ }^{1}$ Acadêmico de Engenharia Civil, Universidade do Extremo Sul Catarinense, nai_bratti@hotmail.com

${ }_{2}^{2}$ Mestre, Engenheiro Civil, Universidade do Extremo Sul Catarinense, augustoawd@gmail.com

${ }^{3}$ Mestre, Engenheiro Civil, Universidade do Extremo Sul Catarinense, marciovito@unesc.net
} 
saios de flexão estática a quatro pontos, quatro com vigas de madeira maciça sem reforço e quatro com vigas de madeira maciça reforçadas por cabo de aço protendido. 0 cabo de aço utilizado foi da classe $6 \times 7$ com

alma de fibra artificial e diâmetro de $1 / 8^{\prime \prime}(3,18 \mathrm{~mm})$, que possui alto teor de carbono e resistência mínima à ruptura de $7,3 \mathrm{kN}$. A seção transversal de todas as vigas foi de $6,5 \mathrm{~cm}$ de largura e $14 \mathrm{~cm}$ de altura, sendo que as vigas reforçadas possuíam dois sulcos quadrados com $5 \mathrm{~mm}$ de lado, para acomodação dos cabos de aço. O comprimento adotado em cada elemento foi de $210 \mathrm{~cm}$, atingindo um vão teórico de $200 \mathrm{~cm}$. Para realizar o método de protensão nas vigas de madeira, foram necessários dois eixos de blocagem bitola 3/8". Ele foi realizado de acordo com sistema utilizado por Cardoso (2013). Os equipamentos utilizados na realização dos ensaios foram o macaco hidráulico e a célula de carga da marca HBM para aplicação e obtenção do carregamento, sendo este aplicado de forma monotônica a fim de simular uma carga estática. Para aferir os deslocamentos verticais, foram acoplados à viga no centro do vão dois medidores LVDT (Linear Variable Differential Transformer). Essas informações foram transmitidas para um computador por meio do sistema de dados QuantumX MX840B da marca HBM. Os ensaios foram realizados no Laboratório Experimental de Estruturas do Parque Científico e Tecnológico (Iparque) da UNESC.

\section{Resultados}

A análise dos resultados mostrou, após a aplicação do método estatístico ANOVA, que as vigas protendidas obtiveram carga máxima, rigidez e ductilidade superiores às vigas não protendidas. A ductilidade pode ser entendida como uma reserva de segurança para a estrutura, pois as vigas protendidas apresentaram uma flecha máxima antes de sofrerem ruptura $185 \%$ maior em média, ocasionando uma situação de grande plastificação das fibras de madeira. Para a seção da viga testada, não houve instabilidade geométrica. Esse resultado é apresentado na Figura 1 (a). A viga protendida no momento do ensaio de flexão estática a quatro pontos também pode ser visualizada na Figura 1 (b). Os demais resultados observados correspondem a um acréscimo médio de $101 \%$ na carga máxima suportada pela viga protendida quando submetida ao esforço de flexão pura. A rigidez da viga protendida se mostrou $33 \%$ superior à viga sem protensão, o que pode representar um acréscimo de $8 \mathrm{kN}$ de carga em uma situação de serviço. Esses resultados podem ser visualizados graficamente na Figura 2 ( $a$ e b), em que os dados estão representados em box plot com as médias e suas variações. 



Figura 1 - Ensaio de flexão estática a quatro pontos: (a) resultados de flecha máxima e (b) viga protendida submetida ao ensaio de flexão Fonte: Elaborada pelos Autores.
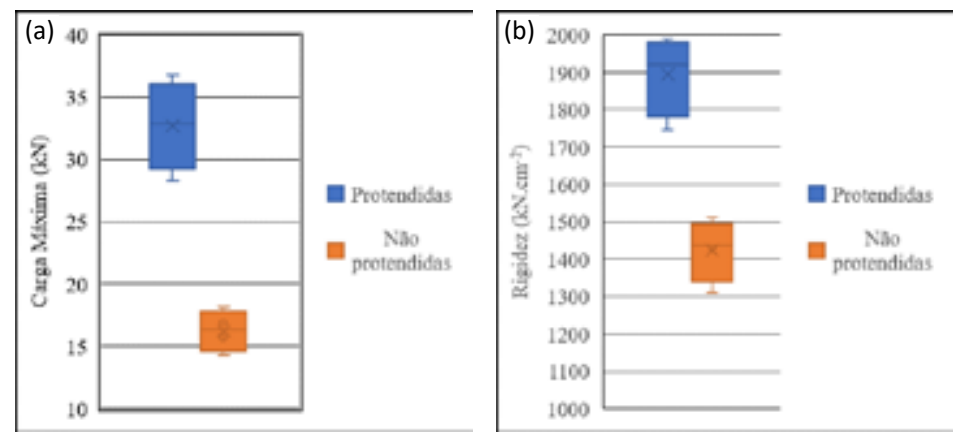

Figura 2 - Ensaio de flexão estática a quatro pontos: (a) resultados em box plot da carga máxima atingida na flexão e (b) rigidez à flexão Fonte: Elaborada pelos Autores.

\section{Conclusões}

É possível afirmar que a viga de madeira protendida com cabos de aço apresenta resultados mecânicos significativamente superiores aos de uma mesma viga não protendida. O colapso das vigas não protendidas ocorreu, na seção transversal analisada, por ruptura frágil das fibras tracionadas. Nas vigas protendidas, esse colapso passou a ocorrer por deformação excessivamente plástica. Fato que corrobora a segurança estrutural e utiliza eficientemente a capacidade das fibras da madeira.

Palavras-Chave: Sistema de protensão; Vigas de madeira; Seção transversal; Ensaio de flexão estática. 


\section{Revista Técnico-Cientifica}

\section{Referências}

CARDOSO, Rafael de Bona. Atenuar o deslocamento vertical em vigas de madeira utilizando cabo de aço. 2013. 21 f. Artigo de Conclusão de Curso

(Graduação em Engenharia Civil) - Universidade do Extremo Sul Catarinense, Criciúma, 2013.

D'AVENI, A.; D'AGATA, G. Post-tensioned timber structures: New perspectives. Construction and Building Materials, v. 153, p. 216-224, 2017.

TAZARV, M.; CARNAHAN, Z.; WEHBE, N. Glulam timber bridges for local roads. Engineering Structures, v. 188, p. 11-23, 2019. 